\title{
O FAVOR DIVORTII E OS SEUS LIMITES NO REGULAMENTO ROMA III: COMENTÁRIO AO ACÓRDÃO DO TRIBUNAL DE JUSTIÇA DA UNIÃO EUROPEIA DE 16 DE JULHO DE 2020, JE CONTRA KF, C-249/19, EU:C:2020:570
}

\author{
FAVOR DIVORTII AND ITS LIMITS ON THE ROME III \\ REGULATION: ANNOTATION ON THE EUROPEAN \\ COURT OF JUSTICE JUDGMENT OF 16 JULY 2020, \\ JE V KF, C-249/19, EU:C:2020:570
}

\author{
JoÃo Gomes De Almeida \\ Professor Auxiliar da Faculdade de Direito \\ Universidade de Lisboa \\ ORCID 0000-0002-0486-6165
}

Recibido: 18.01.2021 / Aceptado: 23.01.2021

DOI: https://doi.org/10.20318/cdt.2021.5997

\begin{abstract}
Resumo: No Acórdão $J E$ contra $K F$, o Tribunal de Justiça da União Europeia responde a uma questão colocada sobre o modo de interpretar o artigo $10{ }^{\circ}$ do Regulamento Roma III. Este comentário examina a solução dada, bem como um obiter dictum efetuado pelo Tribunal de Justiça da União Europeia.

Palavras-chave: Regulamento Roma III, Regulamento (UE) n. ${ }^{\circ}$ 1259/2010, significado de "não preveja o divórcio".

Abstract: In the $J E v K F$ judgment, the European Court of Justice answers a question regarding the interpretation of article 10 of the Rome III Regulation. This annotation examines the solution and an obiter dictum given by the European Court of Justice.

Keywords: Rome III Regulation, Regulation No 1259/2010, meaning of "no provision for divorce".

Sumário: I. Os factos do caso. II. A questão prejudicial. III. A resposta do Tribunal de Justiça da União Europeia. IV. Análise. 1. Considerações gerais. 2. A interpretação do artigo 10. ${ }^{\circ}$ : o elemento literal, o contexto do preceito e as finalidades prosseguidas pelo Regulamento; 3. O obiter dictum sobre a prática jurisprudencial romena. V. Conclusões.
\end{abstract}

\section{Os factos do caso}

1. Dois nacionais romenos casaram entre si em 2 de setembro de 2001. Em 13 de outubro de 2016, um deles intentou ação de divórcio junto dos tribunais romenos. À data da proprositura da ação, os cônjuges residiam habitualmente em Itália.

2. O Tribunal de $1 .^{\text {a }}$ instância romeno considerou a lei italiana aplicável ao litígio, nos termos do artigo $8 .^{\circ}$, alínea $a$ ), do Regulamento Roma III $^{1}$, e decidiu que o pedido apresentado era inadmissível

\footnotetext{
${ }^{1}$ Regulamento (UE) n. ${ }^{\circ}$ 1259/2010 do Conselho, de 20 de Dezembro de 2010, que cria uma cooperação reforçada no domínio da lei aplicável em matéria de divórcio e separação judicial, publicado no Jornal Oficial da União Europeia (doravante JO) L 343, de 29 de dezembro de 2010.
} 
pois, segundo esta lei, uma ação de divórcio como a que foi proposta só podia ser intentada se tivesse havido separação judicial dos cônjuges previamente declarada ou decretada por um tribunal e se tivessem decorrido, pelo menos, três anos entre a data dessa separação e a da propositura da ação.

3. O cônjuge autor interpôs recurso da decisão para o Tribunal de Bucareste, alegando que (i) o artigo $100^{\circ}$ do Regulamento Roma III é aplicável nos casos em que a lei estrangeira designada é mais restritiva do que a lex fori quanto aos requisitos para decretar o divórcio, e (ii) que a aplicação do Direito material italiano no caso concreto violava princípios fundamentais da ordem pública internacional romena, o que justificava o afastamento dessa lei nos termos do artigo 12. ${ }^{\circ}$ do mesmo Regulamento.

\section{A questão prejudicial}

4. O Tribunal de Bucareste suspendeu a instância e colocou a seguinte questão prejudicial ao Tribunal de Justiça da União Europeia:

“[Deve o] artigo $10 .^{\circ}$ do Regulamento n. ${ }^{\circ} 1259 / 2010$ [ser interpretado] no sentido de [que] a expressão "a lei aplicável por força dos artigos $5 .^{\circ}$ ou $8 .^{\circ}$ não preveja o divórcio" deve ser interpretada de forma restritiva e literal, isto é, no sentido de que apenas abrange as situações em que a lei estrangeira aplicável não preveja de nenhuma forma o divórcio, ou deve ser interpretada de forma extensiva, no sentido de que também abrange as situações em que a lei estrangeira aplicável admite o divórcio, mas em condições excecionalmente restritivas, que implicam um processo obrigatório de separação judicial prévio ao divórcio, processo para o qual a lei do foro não prevê disposições processuais equivalentes?’’

5. Em suma, o Tribunal de Bucareste perguntou ao Tribunal de Justiça da União Europeia se a expressão "não preveja o divórcio" deve ser interpretada de forma estrita ou de forma mais ampla, de modo a incluir situações em que a lei estrangeira preveja o divórcio, estabelecendo muito embora requisitos mais exigentes para o decretar.

O Tribunal de Bucareste entendeu limitar a questão prejudicial ao artigo $10{ }^{\circ}$ do Regulamento Roma III, não suscitando qualquer questão sobre a alegação de violação da ordem pública internacional romena (artigo $12 .^{\circ}$ ). Compreende-se a opção. $\mathrm{O}$ artigo $10{ }^{\circ}$ é uma norma inovadora, que não tem equivalente nos demais regulamentos da União Europeia sobre a determinação da lei aplicável. Já o artigo $12 .^{\circ}$ é em tudo semelhante aos artigos $21 .^{\circ}$ e $26 .^{\circ}$, respetivamente, dos Regulamentos Roma I ${ }^{3}$ e Roma $\mathrm{II}^{4}$, que o antecederam, ao artigo $35 .^{\circ}$ do Regulamento sobre sucessões ${ }^{5}$ e aos artigos $31 .^{\circ}$ do Regulamento sobre regimes matrimoniais ${ }^{6}$ e do Regulamento sobre efeitos patrimoniais das parcerias registadas ${ }^{7}$, que o sucederam. Admite-se assim que o concreto litígio colocado perante o Tribunal de Bucareste não tenha suscitado qualquer questão nova sobre a reserva de ordem pública internacional que justificasse a utilização do mecanismo do reenvio prejudicial.

\footnotetext{
${ }^{2}$ Acórdão do TJUE de 16 de julho de 2020, JE contra KF, C-249/19, EU:C:2020:570, considerando n. ${ }^{\circ} 20$.

${ }^{3}$ Regulamento (CE) n. ${ }^{\circ}$ 593/2008 do Parlamento Europeu e do Conselho, de 17 de Junho de 2008, sobre a lei aplicável às obrigações contratuais (Roma I), publicado no JO L 177, de 4 de julho de 2008.

${ }^{4}$ Regulamento (CE) n. ${ }^{\circ}$ 864/2007 do Parlamento Europeu e do Conselho, de 11 de Julho de 2007, relativo à lei aplicável às obrigações extracontratuais (Roma II), publicado no JO L 199, de 31 de julho de 2007.

${ }^{5}$ Regulamento (UE) n. ${ }^{\circ}$ 650/2012 do Parlamento Europeu e do Conselho, de 4 de julho de 2012, relativo à competência, à lei aplicável, ao reconhecimento e execução das decisões, e à aceitação e execução dos atos autênticos em matéria de sucessões e à criação de um Certificado Sucessório Europeu, publicado no JO L 201, de 27 de julho de 2012.

${ }^{6}$ Regulamento (UE) 2016/1103 do Conselho, de 24 de junho de 2016, que implementa a cooperação reforçada no domínio da competência, da lei aplicável, do reconhecimento e da execução de decisões em matéria de regimes matrimoniais, publicado no JO L 183, de 8 de julho de 2016.

${ }^{7}$ Regulamento (UE) 2016/1104 do Conselho, de 24 de junho de 2016, que implementa a cooperação reforçada no domínio da competência, da lei aplicável, do reconhecimento e da execução de decisões em matéria de efeitos patrimoniais das parcerias registadas, publicado no JO L 183, de 8 de julho de 2016.
} 


\section{A resposta do Tribunal de Justiça da União Europeia}

6. O Tribunal de Justiça da União Europeia assinala, preliminarmente, que o artigo $10 .^{\circ}$ constitui uma exceção aos artigos $5 .^{\circ}$ e $8 .^{\circ}$, que consagram as normas de conflitos principal e subsidiária do Regulamento Roma III, e, como tal, deve ser objeto de interpretação estrita ${ }^{8}$.

7. De seguida, o Tribunal de Justiça da União Europeia procede à interpretação do artigo $10 .^{\circ}$ do Regulamento Roma III.

Começa por analisar a letra do preceito, bem como o considerando n. ${ }^{\circ} 24$ do Regulamento Roma III, concluindo que estes elementos não permitem a aplicação do preceito nos casos em que a lei aplicável prevê o divórcio, mas sujeita-o ao cumprimento de requisitos mais restritivos do que os previstos na lei do foro'.

O Tribunal de Justiça da União Europeia destaca, depois, que a expressão "não preveja o divórcio" é igualmente utilizada no artigo $13 .^{\circ}$ do Regulamento Roma III e que o considerando n. ${ }^{\circ} 26$, referindo-se a esta norma, esclarece que a expressão se deve interpretar no sentido de a lei não contemplar o divórcio. Apesar de se referir ao artigo 13. ${ }^{\circ}$, sendo idêntica a expressão utilizada nos dois preceitos, o Tribunal de Justiça da União Europeia considera que as indicações fornecidas pelo considerando são igualmente pertinentes para a interpretação do artigo $10{ }^{\circ}$ do Regulamento Roma III $^{10}$.

Por fim, conclui que a interpretação mais ampla, que subsume ao artigo $10 .^{\circ}$ os casos em que a lei aplicável concede o divórcio em termos mais restritivos do que a lei do foro, é contrária às finalidades prosseguidas pelo Regulamento Roma III, que visa instituir um quadro jurídico claro e completo em matéria de lei aplicável ao divórcio e à separação judicial nos Estados-Membros participantes, garantir a segurança jurídica, a previsibilidade e a flexibilidade nos processos matrimoniais internacionais e, portanto, facilitar a livre circulação de pessoas no interior da União Europeia, bem como impedir uma situação em que um dos cônjuges pede o divórcio antes do outro para garantir que o processo seja regido por uma lei específica que considera mais favorável à salvaguarda dos seus interesses ${ }^{11}$. Isto porque esta interpretação mais ampla (i) obrigaria a uma análise casuística e apreciação subjetiva dos requisitos para a concessão de divórcio da lei aplicável e da lei do foro; (ii) poderia frustar a aplicação de uma lei com a qual os cônjuges têm uma conexão mais estreita, afastando ou a conexão principal (autonomia privada) ou a conexão subsidiária; e (iii) poderia criar um novo incentivo ao forum shopping: sempre que o Regulamento Bruxelas II bis ${ }^{12}$ atribua competência internacional para julgar o divórcio aos tribunais de mais de um Estado-Membro, o cônjuge que pretende o divórcio tenderá a intentar essa ação junto dos tribunais do Estado-Membro cuja lei estabeleça os requisitos de concessão de divórcio menos restritivos ${ }^{13}$.

Conclui, assim, que o facto de a lei aplicável nos termos do artigo $5 .^{\circ}$ ou $8 .^{\circ}$ do Regulamento Roma III prever requisitos mais restritivos para o divórcio do que a lei do foro é irrelevante para efeitos do artigo $10 .^{\circ}$ do mencionado Regulamento ${ }^{14}$.

8. O Tribunal de Justiça da União Europeia debruça-se ainda sobre a prática jurisprudencial romena descrita pelo órgão jurisdicional de reenvio: em litígios como o do presente processo, os pedidos de divórcio “(...) são indeferidos por serem, respetivamente, inadmissíveis, com fundamento em que o direito romeno não prevê o processo de separação judicial, e prematuros, com fundamento em que o divórcio é pedido perante os tribunais romenos, sem que tenha sido previamente declarada ou decretada

\footnotetext{
${ }^{8}$ Acórdão do TJUE de 16 de julho de 2020, JE contra KF, C-249/19, EU:C:2020:570, considerando n. ${ }^{\circ} 23$.

${ }^{9}$ Idem, considerando n. ${ }^{\circ} 26$.

${ }^{10}$ Idem, considerando n. ${ }^{\circ} 28$.

${ }^{11}$ Idem, considerandos n. ${ }^{\circ} \mathrm{s} 30$ e 31 .

${ }^{12}$ Regulamento (CE) n. ${ }^{\circ}$ 2201/2003 do Conselho, de 27 de Novembro de 2003, relativo à competência, ao reconhecimento e à execução de decisões em matéria matrimonial e em matéria de responsabilidade parental e que revoga o Regulamento (CE) n. ${ }^{\circ}$ 1347/2000, publicado no JO L 383, de 23 de dezembro de 2003.

${ }^{13}$ Acórdão do TJUE de 16 de julho de 2020, JE contra KF, C-249/19, EU:C:2020:570, considerandos n. ${ }^{\circ}$ s 32 a 34.

${ }^{14}$ Idem, considerando n. ${ }^{\circ} 36$.
} 
a separação judicial pelos tribunais italianos, ou ainda improcedentes, por estes dois fundamentos conjugados"15.

O Tribunal de Justiça da União Europeia considera que esta prática jurisprudencial, ao impedir a análise do mérito dos pedidos de divórcio, prejudica o efeito útil das normas de conflitos uniformes do Regulamento Roma III e colide, em certa medida, com as normas atributivas de competência internacional do Regulamento Bruxelas II bis, que conferem, no caso presente, competência internacional aos tribunais romenos para julgar o divórcio ${ }^{16}$, concluindo que:

“[a]ssim, numa situação como a que está em causa no processo principal, em que o tribunal competente considera que a lei estrangeira aplicável por força das disposições do Regulamento n. ${ }^{\circ}$ 1259/2010 só permite pedir o divórcio se este tiver sido precedido de uma separação judicial com uma duração de três anos, quando a lei do foro não prevê normas processuais em matéria de separação judicial, esse órgão jurisdicional deve, contudo, não podendo ele próprio decretar essa separação, verificar se estão preenchidos os requisitos materiais previstos pela lei estrangeira aplicável e declará-lo no âmbito do processo de divórcio que lhe foi submetido"17.

\section{Análise}

\section{Considerações gerais}

9. O acórdão que se comenta é apenas o segundo em que o Tribunal de Justiça da União Europeia interpreta normas do Regulamento Roma III. Assinala-se que no primeiro, o acórdão Soha Sahyouni contra Raja Mamisch ${ }^{18}$, o órgão jurisdicional de reenvio também questionou o Tribunal de Justiça da União Europeia sobre como deveria ser interpretado o artigo $10{ }^{\circ}$ do Regulamento Roma III. Em concreto, o órgão jurisdicional de reenvio questionou se o artigo $10 .^{\circ}$ do Regulamento Roma III estabelecia a não aplicação da lei estrangeira designada aplicável pelas normas de conflito do Regulamento sempre que esta fosse discriminatória em abstracto ou apenas quando a lei estrangeira fosse discriminatória em abstracto $e$ no caso concreto submetido ao tribunal ${ }^{19}$.

Esta questão ficou sem resposta porque o Tribunal de Justiça da União Europeia entendeu que o concreto litígio submetido ao órgão jurisdicional de reenvio e que motivou o reenvio prejudical não se inseria no âmbito de aplicação material do Regulamento Roma III, razão pela qual as normas deste não eram aplicáveis.

10. O artigo $10 .^{\circ}$ estabelece dois (dos quatro) novos e distintos limites à aplicação do Direito material estrangeiro consagrados no Regulamento Roma III. Um aplicável nos casos em que o Direito material estrangeiro "não preveja o divórcio" e o outro nos casos em que consagra o divórcio ou a separação judicial em termos discriminatórios em razão do sexo.

No acórdão Soha Sahyouni contra Raja Mamisch a questão prejudicial recaía sobre o limite do acesso discriminatório em razão do sexo. No acórdão que se comenta recai sobre o limite da não previsão do divórcio. Apesar disso, e em face da construção do preceito, a resposta dada pelo Tribunal de Justiça da União Europeia no acórdão em comentário poderá ser extensível ao outro limite consagrado pelo artigo $10 .^{\circ}$ do Regulamento.

\footnotetext{
${ }^{15}$ Idem, considerando n. ${ }^{\mathrm{o}} 39$.

${ }^{16}$ Idem, considerandos n. ${ }^{\mathrm{o}} \mathrm{s} 40$ e 41.

${ }^{17}$ Acórdão do TJUE de 16 de julho de 2020, JE contra KF, C-249/19, EU:C:2020:570, considerando n. ${ }^{\circ} 43$.

${ }^{18}$ Acórdão do TJUE de 20 de dezembro de 2017, Soha Sahyouni contra Raja Mamisch, C-372/16, EU:C:2017:988. Este acórdão foi antecedido por um outro processo, no qual o Tribunal de Justiça proferiu despacho em que se declarou manifestamente incompetente para responder às questões prejudiciais colocadas (Despacho do Tribunal de Justiça (Primeira Secção) de 12 de maio de 2016, proc. C-281/15, EU:C:2016:343).

${ }^{19}$ Acórdão do TJUE de 20 de dezembro de 2017, Soha Sahyouni contra Raja Mamisch, C-372/16, EU:C:2017:988, considerando n. $^{\circ} 25$.
} 


\section{A interpretação do artigo $10 .^{\circ}$ : o elemento literal, o contexto do preceito e as finalidades prosse- guidas pelo Regulamento}

11. O Tribunal de Justiça da União Europeia inicia a sua análise assinalando que o artigo $10 .^{\circ}$ constitui uma exceção às normas de conflitos principal e subsidiária (artigos $5 .^{\circ} \mathrm{e} 8 .^{\circ}$ ) do Regulamento Roma III e que, por isso, deve ser objeto de interpretação estrita.

Considera-se que, ao referir-se a uma interpretação estrita, o Tribunal de Justiça da União Europeia não sustenta que o preceito deva ser objeto de uma interpretação restritiva, no sentido de que o intérprete (e o órgão jurisdicional de reenvio) deve encurtar o significado das expressões usadas no preceito para as adequar ao seu espírito. Antes nos parece que se pretende garantir uma interpretação declarativa, que não amplie ou restrinja o significado das expressões utilizadas no artigo $10 .^{\circ}$ do Regulamento.

A esta luz, concorda-se com a conclusão do Tribunal de Justiça da União Europeia de que o sentido literal possível da expressão "não preveja o divórcio" não inclui situações em que a lei designada aplicável consagra o instituto do divórcio, mas fá-lo em condições excecionalmente restritivas ou mais restritivas do que a lei do foro.

Apenas indo além do sentido literal possível se poderia incluir na previsão deste limite à aplicação do Direito material estrangeiro situações em que se exige uma ponderação casuística - que poderia estar na mente do órgão jurisdicional de reenvio, quando formulou a questão em termos de uma consagração do divórcio em condições excecionalmente restritivas, procurando equiparar à não previsão situações que, no caso concreto, não poderiam conduzir ao decretamento do divórcio - ou uma comparação entre a lei estrangeira e a lei do foro ${ }^{20}$.

12. A nível contextual, o Tribunal de Justiça da União Europeia releva que a expressão "não preveja o divórcio" é também utilizada num dos novos limites à aplicação do Direito material estrangeiro estabelecidos pelo artigo $13 .^{021} \mathrm{e}$ que o considerando n. ${ }^{\circ} 26$ indica que esta expressão deve ser interpretada no sentido de que a lei não contempla o instituto do divórcio.

Assinala - como alguma doutrina já o havia feito ${ }^{22}$ - que as indicações fornecidas pelo considerando são igualmente pertinentes para a interpretação do artigo $10 .^{\circ}$ do Regulamento Roma III.

\footnotetext{
${ }^{20}$ Recorda-se que, de acordo com a jurisprudência do Tribunal de Justiça da União Europeia, os preceitos que constituem desvios à regra geral não admitem interpretação extensiva. Neste sentido, veja-se, em sede de interpretação do Regulamento (CE) n. ${ }^{\circ}$ 1346/2000 do Conselho, de 29 de Maio de 2000, relativo aos processos de insolvência, publicado no JO L 160, de 30 de junho de 2000, o Acórdão de 15 de outubro de 2015, Nike European Operations Netherlands, C-310/14, EU:C:2015:690, considerando n. ${ }^{\circ}$ 21, e o Acórdão de 8 de junho de 2017, Vinyls Italia, C-54/16, ECLI:EU:C:2017:433, considerando n. ${ }^{\circ} 36$; e, em sede do Regulamento (CE) n. ${ }^{\circ} 44 / 2001$ do Conselho, de 22 de Dezembro de 2000, relativo à competência judiciária, ao reconhecimento e à execução de decisões em matéria civil e comercial, publicado no JO L 12, de 16 de janeiro de 2001, e do Regulamento (UE) n. ${ }^{\circ}$ 1215/2012 do Parlamento Europeu e do Conselho, de 12 de dezembro de 2012, relativo à competência judiciária, ao reconhecimento e à execução de decisões em matéria civil e comercial (reformulação), publicado no JO L 351, de 20 de dezembro de 2012, o Acórdão de 4 de outubro de 2018, Feniks, C-337/17, EU:C:2018:805, considerando n. ${ }^{\circ} 37$, o Acórdão de 14 de julho de 2016, Granarolo, C-196/15, EU:C:2016:559, considerando n. ${ }^{\circ}$ 18, e o Acórdão de 18 de julho de 2013, ÖFAB, C-147/12, EU:C:2013:490, considerando n. ${ }^{\circ} 31$.

${ }^{21}$ Este limite prevê que o órgão aplicador do direito do Estado-Membro participante do foro não está obrigado a decretar o divórcio, nos termos do Direito material designado aplicável por força das normas do Regulamento Roma III, quando o Direito material do foro não preveja o divórcio e ficou conhecido como a cláusula maltesa. Na sua génese está um compromisso político. O Regulamento Roma III viria a ser o primeiro instrumento da União Europeia a ter sido adotado através de uma cooperação reforçada e, como tal, almejava-se uma participação o mais alargada possível.

Malta era, à data das negociações, o único Estado-Membro da União Europeia cujo Direito material desconhecia o instituto do divórcio. Seria natural que não participasse nesta cooperação reforçada. No entanto, negociou o seguinte compromisso, vertido neste limite: Malta participava na cooperação reforçada, mas os órgãos aplicadores do direito malteses em caso algum ficavam obrigados a dissolver um vínculo matrimonial por força das regras do Regulamento Roma III. Porém, em 2011 (ainda antes de as normas do Regulamento serem aplicáveis), Malta introduziu o instituto do divórcio no seu Direito material. Deste modo, o Regulamento Roma III contém uma previsão normativa que é, atualmente, de verificação impossível, não sendo expectável que tal se altere no futuro.

${ }^{22}$ Cf., neste sentido, S. Corneloup et al., Droit européen du divorce European divorce law, Paris, LexisNexis, 2013, pp. 597-598; e J.G. de Almeida, O Divórcio em Direito Internacional Privado, Coimbra, Almedina, 2017, pp. 438-439.
} 
De facto, entende-se que seria dificilmente compreensível que o legislador da União Europeia utilizasse, no mesmo Regulamento e para tratar questões referentes à mesma matéria (limites à aplicação da lei estrangeira), a mesma expressão conferindo-lhe significados jurídicos diferentes.

13. O Regulamento Roma III visa, em síntese, garantir a segurança jurídica, a previsibilidade e a flexibilidade nos processos matrimoniais internacionais e mitigar o forum shopping decorrente das múltiplas normas atributivas de competência internacional consagradas no Regulamento Bruxelas II bis. Uma análise casuística e comparativa entre a lei aplicável e a lei do foro contraria, no entender do Tribunal de Justiça da União Europeia, estas finalidades, pois diminui a segurança jurídica e a previsibilidade, pode impedir a aplicação da lei com a qual os cônjuges tem uma conexão mais estreita e pode criar um novo incentivo ao forum shopping.

No Regulamento Bruxelas II bis, em matéria de competência internacional, o favor divortii advém, primacialmente, da consagração de múltiplas normas atributivas de competência internacional de aplicação concorrente ${ }^{23}$. Sendo internacionalmente competentes os tribunais de vários Estados-Membros, o cônjuge autor pode intentar a ação nos tribunais de qualquer um desses Estados-Membros. A admissibilidade do forum shopping funciona, no caso concreto das ações de divórcio, como favorecimento das decisões que proferem o divórcio porque, em regra, o autor destas ações é o cônjuge que pretende a dissolução do vínculo matrimonial e escolherá de entre as jurisdições internacionalmente competentes aquela que considera ser mais favorável à sua pretensão.

O Regulamento Roma III, ao uniformizar as normas de Direito de conflitos do divórcio e separação judicial, limitou, nos Estados-Membros participantes, a amplitude deste favor divortii. Mesmo que sejam internacionalmente competentes os tribunais de vários Estados-Membros participantes, a lei reguladora do divórcio e da separação judicial será a mesma em todos eles, salvo se ao caso for aplicável uma lei estrangeira e se considerar verificado algum dos limites à aplicação do Direito material estrangeiro. Estes limites estão, por definição, numa relação inversa com as finalidades prosseguidas pelo Regulamento. Quanto maior for o campo de aplicação destes limites, menor será a segurança e previsibilidade jurídicas e menor será a mitigação do forum shopping.

A coincidência forum ius não é um fim em si mesma. Nem sempre as razões que justificam determinada conexão atributiva de competência internacional justificam idêntica conexão para a determinação da lei aplicável. Uma conexão pode ser suficientemente estreita para estabelecer a competência internacional e, ainda assim, não ser suficientemente estreita para determinar o Direito material que vai reger determinada situação. O que, conjugado com a estatuição do artigo $10 .^{\circ}$ do Regulamento de aplicação da lex fori, pode conduzir, em muitos casos, ao afastamento da aplicação de uma lei que tem uma conexão próxima com a situação em favor da lei do foro, que pode não a ter.

14. Em conclusão, percorrido o iter interpretativo do Tribunal de Justiça da União Europeia, não merece reparos a interpretação de que a expressão "não preveja o divórcio", presente no artigo $10 .^{\text { }}$ (e no

\footnotetext{
${ }^{23}$ Comummente designados na doutrina como critérios alternativos. Cf., por exemplo, A. BorRÁs, «Relatório Explicativo da Convenção, elaborada com base no artigo K.3 do Tratado da União Europeia, relativa à competência, ao reconhecimento e à execução de decisões em matéria matrimonial», JOCE C 221/27, de 16 de julho de 1998, p. 37 ; J. GonZALEz CAMPos, «Diversification spécialisation flexibilisation et matérialisation des règles de droit international prive», Recueil des cours de l'Académie de droit international de La Haye, 2000, n 287, p. 364 ; H. SсHACK, «The New International Procedure in Matrimonial Matters in Europe», European Journal of Law Reform, 2002, n 1, p. 43 ; M.H. BRITO, «O Regulamento (CE) n. ${ }^{\circ} 2201 / 2003$ do Conselho, de 27 de Novembro de 2003, relativo à competência, ao reconhecimento e à execução de decisões em matéria matrimonial e em matéria de responsabilidade parental», in Estudos em Memória do Professor Doutor António Marques dos Santos, I, Coimbra, Almedina, 2005, p. 324 ; B. NAScimBENE, Divorzio, diritto internazionale privato e dell'Unione europea, Milão, Giuffrè Editore, 2011, p. 77 ; G. BIAGIONI, «Alcuni caratteri generali del forum necessitatis nello spazio giudiziario europeo», Cuadernos de derecho transnacional, março de 2012, vol. 4, n 1, p. 25 ; M.Á. SÁNCHEz JimÉnEz, El Divorcio Internacional En La Unión Europea (Jurisdicción y Ley Aplicable), Navarra, Editorial Aranzadi, 2013, p. 33 ; R.M.M. RAmos, «Um Novo Regime do Divórcio Internacional na União Europeia», in Estudos de Direito Internacional Privado da União Europeia, Coimbra, Imprensa da Universidade de Coimbra, 2016, p. 191 ; e L. de L. PINHeIRo, Direito Internacional Privado. Competência internacional, III, tomo I, Lisboa, AAFDL, 2019, p. 285. O Tribunal de Justiça da União Europeia utiliza também esta designação. Veja-se, por exemplo, o Acórdão de 16 de julho de 2009, Hadadi, proc. C-168/08, EU:C:2009:474, considerando n. ${ }^{\circ} 48$.
} 
artigo $13 .^{\circ}$ ) do Regulamento Roma III deve ser interpretada no sentido de que “(...) abrange apenas as situações em que a lei estrangeira aplicável não preveja de forma alguma o divórcio" ${ }^{24}$, isto é, abrange apenas as situações em que o Direito material desconhece (não consagra) o instituto do divórcio.

A pronúncia esclarece que este limite deve ser verificado em abstrato, ou seja, o intérprete e os órgãos aplicadores do Direito devem verificar apenas se o Direito material designado aplicável nos termos dos artigos $5 .^{\circ}$ e $8 .^{\circ}$ do Regulamento Roma III consagra ou não o instituto do divórcio. Considerações sobre o modo como se encontra consagrado, nomeadamente sobre os requisitos estabelecidos para o decretamento do divórcio e o carácter (excecionalmente) restritivo dos mesmos, ou sobre a existência ou não de laços significativos com a lex fori, são irrelevantes para a análise deste limite, consagrado no artigo $10 .^{\circ}$ do Regulamento Roma III $^{25}$. Este ponto é extensível ao outro limite à aplicação do Direito material estrangeiro (discriminição em razão do género no acesso ao divórcio e à separação judicial) consagrado no artigo $10 .^{\circ}$ do Regulamento Roma III, em virtude do modo como se encontra redigido o preceito.

Tais considerações $n a \tilde{o}$ são vedadas pelo Regulamento Roma III. No entanto, devem efetuar-se na análise da reserva de ordem pública internacional ${ }^{26}$.

\section{O obiter dictum sobre a prática jurisprudencial romena}

15. Como se referiu supra em 8., o Tribunal de Justiça da União Europeia analisa ainda uma prática jurisprudencial romena descrita pelo órgão jurisdicional de reenvio. Com base na ideia de que a mesma prejudica o efeito útil das normas de conflitos uniformes do Regulamento Roma III e colide, em certa medida, com as normas atributivas de competência internacional do Regulamento Bruxelas II bis, o Tribunal de Justiça da União Europeia conclui:

“[a]ssim, numa situação como a que está em causa no processo principal, em que o tribunal competente considera que a lei estrangeira aplicável por força das disposições do Regulamento $\mathrm{n} .{ }^{\circ}$ 1259/2010 só permite pedir o divórcio se este tiver sido precedido de uma separação judicial com uma duração de três anos, quando a lei do foro não prevê normas processuais em matéria de separação judicial, esse órgão jurisdicional deve, contudo, não podendo ele próprio decretar essa separação, verificar se estão preenchidos os requisitos materiais previstos pela lei estrangeira aplicável e declará-lo no âmbito do processo de divórcio que lhe foi submetido"27.

16. Esta conclusão é aquela que nos suscita mais dúvidas e interesse. Antes de nos debruçarmos sobre ela, seguem-se duas notas prévias.

A primeira para retificar o que parece ser um lapso - sem consequências de maior - na análise do Direito material italiano. O órgão jurisdicional de reenvio "(...) considerou que, segundo o direito italiano, uma ação de divórcio apresentada em circunstâncias como as da ação principal só podia ser intentada se tivesse havido separação judicial dos cônjuges previamente declarada ou decretada por um tribunal e se tivessem decorrido, pelo menos, três anos entre a data dessa separação e aquela em que a ação de divórcio foi intentada judicialmente" 28 , entendimento aceite pelo Tribunal de Justiça da União Europeia. A lei de 6 de maio de 2015, n. ${ }^{\circ}$ 55, alterou a lei de 1 de dezembro de 1970, n. ${ }^{\circ} 898$, que disciplina o divórcio, reduzindo o prazo de três anos para doze ou seis meses, consoante a separação judicial tenha sido decretada sem ou com o consentimento do outro cônjuge. Esta lei entrou em vigor no dia 26 de maio de 2015 e, nos termos do seu artigo $3 .^{\circ}$, aplica-se a todos os processos de divórcio que estejam

\footnotetext{
${ }^{24}$ Acórdão do TJUE de 16 de julho de 2020, JE contra KF, C-249/19, EU:C:2020:570, parte decisória.

${ }^{25} \mathrm{O}$ que já vinha sendo assinalado na doutrina, nomeadamente, S. ConNeloup et al., Droit européen du divorce European divorce law, op. cit., p. 602 ; e C. KOHLER, «Le choix de la loi applicable au divorce - Interrogations sur le règlement « Rome III » de l'Union européenne -», in Grenzen überwinden - Prinzipien bewahren Festschrift für Bernd von Hoffmann zum 70. Geburtstag, Bielefeld, Gieseking, 2011, p. 212 ; e «L'autonomie de la volonté en droit international privé: un principe universel entre libéralisme et étatisme», Recueil des cours de l'Académie de droit international de La Haye, 2013, n 359, p. 427.

${ }^{26}$ Artigo 12. ${ }^{\circ}$ do Regulamento Roma III.

${ }^{27}$ Acórdão do TJUE de 16 de julho de 2020, JE contra KF, C-249/19, EU:C:2020:570, considerando n. ${ }^{\circ} 43$.

${ }^{28}$ Acórdão do TJUE de 16 de julho de 2020, JE contra KF, C-249/19, EU:C:2020:570, considerando n. ${ }^{\circ} 15$. Itálicos aditados.
} 
em curso nessa data. Considerando que a ação de divórcio que motivou o reenvio prejudicial foi intentada em 13 de outubro de 2016, o prazo aplicável seria o de 12 ou 6 meses.

A segunda nota prévia para assinalar que este obiter dictum releva apenas quando o foro seja o de um Estado-Membro participante cujo Direito não preveja o instituto da separação judicial. Dos 17 Estados-Membros participantes, 9 não prevêem no seu Direito material o instituto da separação judicial ${ }^{29}$.

17. O Tribunal de Justiça da União de Europeia parece defender, ao abrigo da necessidade de garantir o efeito útil das normas do Regulamento Roma III, que os tribunais dos Estados-Membros participantes cujo Direito material não prevê o instituto da separação judicial - quando tenham perante eles uma ação transnacional cujo Direito material estrangeiro aplicável estabeleça, como condição para decretar o divórcio, que se tenha previamente decretado a separação judicial dos cônjuges e que essa se mantenha por um determinado período de tempo - devem "verificar se estão preenchidos os requisitos materiais previstos pela lei estrangeira aplicável e declará-lo no âmbito do processo de divórcio que lhe foi submetido".

Não parece ser inteiramente claro a que se refere o Tribunal de Justiça da União Europeia quando afirma que o tribunal nacional deve "declará-lo no âmbito do processo de divórcio que the foi submetido". Avançam-se três hipóteses: (i) declarar o divórcio; (ii) declarar a separação judicial; ou (iii) declarar que estão preenchidas as condições para ser pedida (e decretada) a separação judicial entre os cônjuges.

A primeira hipótese avançada tem a seu favor apenas a concordância de género, quando se confronta $o$ divórcio com $a$ separação judicial. Esta interpretação deve, no entanto, ser afastada. A definição abstrata da situação no considerando n. $^{\circ} 43$ expressamente menciona que o tribunal nacional considera que a lei estrangeira aplicável "só permite pedir o divórcio se este tiver sido precedido de uma separação judicial com uma duração de três anos". Assim, a interpretação da expressão "declará-lo" como "declarar o divórcio" colidiria direta e frontalmente com este entendimento, o que mereceria sempre uma redação mais explícita até porque, no mesmo considerando, o Tribunal de Justiça da União Europeia avança a hipótese de o tribunal nacional não poder decretar a separação judicial ("não podendo ele próprio decretar essa separação"). Considerando o entendimento do tribunal nacional de que o divórcio, nos termos da lei estrangeira, só pode ser declarado se previamente tiver sido decretada separação judicial e os cônjuges se mantenham separados durante determinado período de tempo, e que é aceite a eventualidade de o tribunal nacional não poder decretar ele próprio essa separação judicial, então é forçoso concluir que a expressão "declará-lo" não pode significar declarar o divórcio.

No confronto entre as restantes duas hipóteses, a menção à eventualidade do tribunal nacional do foro não poder ele próprio decretar a separação judicial é igualmente um elemento de interpretação ponderoso, no sentido de que a expressão "declará-lo" não pode ser interpretada como declarar a separação judicial. A este argumento junta-se o elemento literal da discordância de género e, com maior relevância, a pronominalização do verbo declarar que parece referir-se ao resultado da verificação do preenchimento dos requisitos materiais previstos pela lei estrangeira aplicável em matéria de separação judicial ${ }^{30}$.

\footnotetext{
${ }^{29}$ A separação judicial encontra-se prevista no Direito material belga (cf. artigo 311bis do Código Civil belga), espanhol (cf. artigos $81 .^{\circ}$ e ss. do Código Civil espanhol), francês (cf. artigos $296 .^{\circ}$ e ss. do Código Civil francês), italiano (cf. artigos 151. ${ }^{\circ}$ e ss. do Código Civil italiano), luxemburguês (cf. artigos $306 .^{\circ}$ e ss. do Código Civil luxemburguês), lituano (cf. https://ejustice.europa.eu/content_divorce-45-1t-en.do?member=1\#toc_4, consultado pela última vez em 11 de janeiro de 2021), maltês (cf. artigos $35 .^{\circ}$ e ss. do Código Civil maltês) e português (cf. artigos 1794. ${ }^{\circ}$ e ss. do Código Civil português).

${ }^{30}$ Apontam neste sentido as versões em língua inglesa ("Thus, in a situation such as that at issue in the main proceedings, in which the court having jurisdiction considers that the foreign law applicable pursuant to the provisions of Regulation No 1259/2010 permits an application for divorce only if that divorce has been preceded by a legal separation of three years, whereas the law of the forum does not lay down any procedural rules in relation to legal separation, that court must nevertheless, since it cannot itself declare such a separation, determine whether the substantive conditions laid down in the applicable foreign law are satisfied and make that finding in the context of the divorce proceedings before it.") e espanhola ("Así, en una situación como la que es objeto del litigio principal, en la que el tribunal competente considera que la ley extranjera aplicable en virtud de las disposiciones del Reglamento $n^{\circ}{ }^{1259 / 2010}$ únicamente permite solicitar el divorcio si este ha ido precedido de una separación judicial de una duración de tres años, mientras que la ley del foro no contempla normas de procedimiento en materia de separación judicial, dicho tribunal debe, no obstante, ya que no puede declarar él mismo tal separación, comprobar que se cumplen las condiciones de fondo previstas en la ley extranjera aplicable y hacerlo constar en el marco del procedimiento de divorcio del que conoce.").
} 
18. Aqui chegados, questiona-se se, com este obiter dictum, o Tribunal de Justiça da União Europeia pretendeu convergir ou divergir da opinião expressa pelo Advogado-Geral neste processo ${ }^{31}$. O Advogado-Geral sustentou, em resumo, que o tribunal nacional era obrigado a pronunciar-se sobre o mérito da ação de divórcio intentada. Para esse efeito, e para evitar que as normas do Regulamento Roma III fossem parcialmente inoperantes, deve o tribunal nacional aplicar "os requisitos materiais previstos pela lei aplicável e afast[ar] a aplicação de eventuais requisitos processuais previstos por essa lei, quando a lei processual do foro não preveja o preenchimento destes requisitos. Assim, se, num determinado caso, estiverem preenchidos os requisitos materiais que permitem que seja decretada a separação judicial, o tribunal do foro pode sanar a circunstância de não poder decretar ele próprio a separação judicial, prescindindo desse requisito processual da lei estrangeira" ${ }^{\prime 2}$. Conclui, assim, que o tribunal nacional deve "(...) confirmar, na decisão a proferir no processo de divórcio, que o requisito da separação legal estava preenchido. A fim de obter a prova do cumprimento deste requisito, o tribunal ao qual o litígio foi submetido deve, na medida do necessário, adaptar a lei processual do foro"33. Assim, o Advogado-Geral aderiu à argumentação do Governo Alemão e à solução avançada pela Comissão Europeia para o caso subjacente a este pedido de reenvio prejudicial ${ }^{34}$.

Tendo presente as conclusões do Advogado-Geral, é defensável o entendimento de que o obiter dictum constitui uma síntese (imperfeita) da posição sustentada pelo Advogado-Geral e indicação de que o Tribunal de Justiça da União Europeia a ela aderiu.

19. Quer o obiter dictum quer a posição do Advogado-Geral parecem encontrar justificação na prática jurisprudencial romena conduzir (a maioria da vezes) ${ }^{35}$ a uma decisão judicial que não se pronuncia sobre o mérito. Sem pretender discutir a prática jurisprudencial romena, sempre se dirá que a verificação de que não se encontra preenchido o requisito (existência de decisão judicial prévia, transitada em julgado, de separação judicial dos cônjuges) de que depende o pedido de divórcio do autor, deve conduzir a uma decisão de improcedência do pedido ${ }^{36}$.

No litígio concreto que motivou o reenvio prejudicial, foi pedido o divórcio, mas não foi “(...) demonstrada a existência de uma decisão judicial que declarasse ou decretasse essa separação (...)" "37, isto é, nenhum dos cônjuges provou que tinha sido proferida decisão de separação judicial. Deste modo, e ao abrigo da lei italiana, designada aplicável ao abrigo do artigo $8 .^{\circ}$ do Regulamento Roma III, o tribunal deveria proferir uma decisão de improcedência do pedido, por não se ter provado a causa de pedir.

Esta seria, pensa-se, a decisão a que chegariam os tribunais italianos ou os tribunais de Estados-Membros participantes cujo Direito material prevê o instituto da separação judicial ${ }^{38}$, caso a ação tivesse (ou, no caso destes últimos, pudesse ter) aí sido intentada, nos mesmos termos. Atente-se que o cônjuge autor não pede a separação judicial, pede o divórcio. E, de acordo com o Direito material aplicável ao caso, o divórcio só pode ser decretado se previamente tivesse sido decretada a separação judicial dos cônjuges, por decisão transitada em julgado. O cônjuge autor parece reconhecer (implicitamente) isso mesmo, pois a sua posição assenta não numa incorreta interpretação ou aplicação do Direito mate-

${ }^{31}$ Conclusões do Advogado-Geral Evgeni Tanchev, apresentadas em 26 de março de 2020, C-249/19, ECLI:EU:C:2020:231, considerandos $n .^{\circ} \mathrm{s} 59$ e ss.

${ }^{32}$ Idem, considerando n. ${ }^{\circ} 65$.

${ }^{33}$ Idem, considerando n. ${ }^{\circ} 70$, quarto parágrafo.

${ }^{34}$ Conclusões do Advogado-Geral Evgeni Tanchev, apresentadas em 26 de março de 2020, C-249/19, ECLI:EU:C:2020:231, considerandos n. ${ }^{\circ}$ s 63,65 e 66.

${ }^{35}$ Dizemos a maioria das vezes, porque resulta do acórdão (considerando n. ${ }^{\text {o } 39)}$ e das conclusões do Advogado-Geral (considerando $\mathrm{n}^{\circ}{ }^{\mathrm{o}} 23$ ) que por vezes eram proferidas decisões de improcedência do pedido.

${ }^{36}$ Admitindo que a aplicação da lei estrangeira designada aplicável não conduz, no caso concreto, a um resultado manifestamente incompatível com a ordem pública internacional do foro (artigo 12. ${ }^{\circ}$ do Regulamento Roma III).

${ }^{37}$ Acórdão do TJUE de 16 de julho de 2020, JE contra KF, C-249/19, EU:C:2020:570, considerando n. ${ }^{\circ} 16$.

${ }^{38}$ Desde que não considerassem que a aplicação do Direito material italiano conduzisse, no caso concreto, a um resultado manifestamente incompatível com a sua ordem pública internacional, caso em que, nos termos do artigo $12 .^{\circ}$ do Regulamento Roma III, o Direito material italiano seria afastado. 
rial italiano, mas sim na ideia de que o Direito material italiano deveria ser afastado em favor do Direito material romeno, por força dos artigos $10 .^{\circ}$ e $12 .^{\circ}$ do Regulamento Roma III ${ }^{39}$.

Como tal, entende-se que, sendo possível uma decisão sobre o mérito, cai por terra a solução da Comissão Europeia, a que aderiu o Advogado-Geral e também (aparentemente) o Tribunal de Justiça da União Europeia. Ainda assim, analisam-se de seguida mais detalhadamente os argumentos esgrimidos pelo Advogado-Geral.

\section{Sustenta o Advogado-Geral que:}

"Concordo com Governo alemão no sentido de que os Estados-Membros que participam na cooperação reforçada criada pelo Regulamento n. ${ }^{\circ}$ 1259/2010 devem garantir que tanto o divórcio como a separação judicial possam ser decididos pelos seus tribunais. Por conseguinte, em vez de considerar que a separação judicial deve ser previamente decidida ou decretada perante os tribunais italianos, os tribunais romenos devem, na minha opinião, seguir eles próprios esse processo e aplicar, por analogia, as regras processuais nacionais relativas ao divórcio ou até adaptar as regras processuais estrangeiras (italianas) relativas à separação judicial (em conjugação com as regras nacionais romenas). Caso contrário, as disposições do Regulamento n. ${ }^{\circ}$ 1259/2010 seriam parcialmente inoperantes" ${ }^{\prime 40}$.

O argumento de que todos os Estados-Membros participantes no Regulamento Roma III devem garantir que os seus tribunais podem decidir processos judiciais de divórcio ou de separação judicial, no caso concreto, não parece procedente pelo simples facto de que não foi pedido aos tribunais romenos que decretassem a separação judicial dos cônjuges. Se o cônjuge autor tivesse pedido a separação judicial e os tribunais romenos tivessem proferido decisão de extinção da instância, com o argumento de que não existem normas processuais romenas que regulem o processo de separação judicial, havia que ponderar o argumento e o risco de as normas do Regulamento Roma III serem parcialmente inoperantes. Porém, o cônjuge autor não pediu a separação judicial, pediu o divórcio. E, no caso concreto e de acordo com a lei italiana, para este ser decretado era necessário que previamente tivesse sido decretada a separação judicial, por decisão judicial transitada em julgado.

O entendimento de que os tribunais romenos deveriam “(...) seguir eles próprios esse processo e aplicar, por analogia, as regras processuais nacionais relativas ao divórcio ou até adaptar as regras processuais estrangeiras (italianas) relativas à separação judicial (em conjugação com as regras nacionais romenas)" sem que no processo tivesse sido pedida a separação judicial suscita, no mínimo, dúvidas e reservas, pois muitos do Estados-Membros participantes consagram, nesta matéria, o princípio do dispositivo $^{41}$ e o Direito material designado aplicável exige uma duração mínima da separação judicial, que não estaria preenchida se os tribunais romenos decretassem a separação judicial no mesmo processo em que é pedido (e eventualmente decretado) o divórcio.

21. De acordo com a solução secundada pelo Advogado-Geral haveria que aplicar os requisitos materiais e afastar os requisitos processuais previstos pela lei estrangeira designada aplicável, no caso concreto a lei italiana.

A lei italiana prevê, no que ao caso concreto interessa, que o divórcio pode ser decretado se: (i) existir prévia decisão judicial transitada em julgado que decrete a separação judicial dos cônjuges; e (ii) a separação judicial dure há, pelo menos, 6 ou 12 meses, consoante tenha sido ou não proferida com mútuo consentimento ${ }^{42}$. $\mathrm{O}$ segundo requisito está formulado tomando por referência momentos processuais, nomeadamente a data da instauração da ação de divórcio, mas crê-se que daí não pode

\footnotetext{
${ }^{39}$ Acórdão do TJUE de 16 de julho de 2020, JE contra KF, C-249/19, EU:C:2020:570, considerando n. ${ }^{\circ}$ s 17 a 19.

${ }^{40}$ Conclusões do Advogado-Geral Evgeni Tanchev, apresentadas em 26 de março de 2020, C-249/19, ECLI:EU:C:2020:231, considerando $n .^{\circ} 63$.

${ }^{41}$ A compatibilidade do princípio (de Direito nacional) do dispostivo com o princípio (de Direito da União Europeia) da efetividade foi confirmada pelo Tribunal de Justiça da União Europeia no Acórdão de 14 de dezembro de 1995, Van Schijndel e vanVeen, C-430/93, EU:C:1995:441, considerandos n. ${ }^{\circ} 20$ a 22.

${ }^{42}$ Artigo $3 .^{\circ},{ }^{\circ} .^{\circ}$, alínea $b$ ) da Lei de 1 de dezembro de 1970, n. $^{\circ} 898$, na redação atualmente vigente.
} 
imediatamente concluir-se que se trata de um requisito processual. A ideia subjacente a este período de 6 ou 12 meses é, pensa-se, a de garantir um período de reflexão para os cônjuges, assegurando-se assim uma intenção firme de pôr fim ao matrimónio. Algo de semelhante ocorre, por exemplo, em Espanha. De acordo com o Direito material espanhol, o divórcio é concedido desde que um dos cônjuges o requeira, sem necessidade de indicação de causa e desde que entre a apresentação do pedido de divórcio e a celebração do casamento tenham decorrido pelo menos três meses ${ }^{43}$.

De acordo com o Advogado-Geral seria a exigência de uma decisão judicial prévia, transitada em julgado, de separação judicial dos cônjuges que constituiria um requisito processual que deveria ser afastado, quando o tribunal nacional do foro não pudesse ele próprio decretar a separação judicial ${ }^{44}$. Caberia assim ao tribunal nacional do foro determinar se, no caso concreto, existiriam factos que tornem intolerável a continuação da coabitação dos cônjuges ou causem graves prejuízos à educação dos fi1 hos ${ }^{45}$. Caso a resposta fosse positiva, i.e., caso se entendesse que estavam preenchidas as condições materiais previstas pela lei italiana para decretar a separação judicial, o tribunal do foro deveria prescindir de exigir uma decisão prévia de separação judicial, subentendendo-se que deveria considerar preenchido esse requisito para decretar o divórcio.

Discorda-se deste entendimento. Desde logo porque para esta solução ser efetiva, ela obriga a reconfigurar também o segundo requisito (duração da separação judicial por um determinado período de tempo), que nos parece ser inequivocamente um requisito material. Mesmo que se aceite a solução de que o tribunal nacional do foro deve prescindir da existência de uma decisão judicial prévia, transitada em julgado, de separação judicial dos cônjuges, em favor da verificação de que, no caso concreto, estavam reunidas as condições para o proferimento dessa decisão, "sanando-se" assim a sua falta, sempre se deveria concluir que, sendo essa verificação efetuada no processo de divórcio, não havia decorrido o tempo mínimo exigido pela lei italiana. Apenas a reconfiguração desta exigência - passando esta, por exemplo, a referir-se há quanto tempo se encontravam preenchidas as condições para um dos cônjuges obter uma decisão de separação judicial - parece permitir ultrapassar este obstáculo. Com esta reconfiguração perde-se, porém, o período de reflexão imposto aos cônjuges, que parece ser a ratio do requisito.

22. O Advogado-Geral entende que esta solução “(...) não encoraja indevidamente o forum shopping" ${ }^{46}$, uma vez que o autor da ação não se poderia furtar ao cumprimento dos requisitos materiais da lei designada aplicável pelo Regulamento Roma III. Este entendimento não parece correto, até porque, como se referiu no parágrafo precedente, a solução, para ser efetiva, obriga a uma reconfiguração do requisito (material) do tempo mínimo de duração que impossibilita a prossecução daquela que parece ser a sua ratio. Entende-se também que há uma promoção indevida, no sentido de não querida pelo Regulamento Roma III, do forum shopping. Dos elementos factuais do litígio descritos quer no Acórdão quer nas Conclusões do Advogado-Geral resulta que o cônjuge autor podia ter intentando a ação de divórcio junto dos tribunais romenos (como o fez) ou dos tribunais italianos. A justificação para a propositura da ação junto dos tribunais romenos (tribunais do Estado da nacionalidade comum dos cônjuges), ao invés de junto dos tribunais italianos (tribunais do Estado da residência habitual comum dos cônjuges) parece ter sido a vontade de o cônjuge autor obter uma decisão de divórcio sem previamente ter sido declarada judicialmente a separação dos cônjuges. Este objetivo - que o cônjuge autor visava obter mediante o afastamento da lei material estrangeira e aplicação da lex fori - é alcançado mediante a (profunda) reconfiguração dos requisitos previstos pela lei italiana para a concessão do divórcio. O Regulamento Roma III visou limitar o forum shopping admitido pelo Regulamento Bruxelas II bis, através da uniformização das regras de conflitos aplicáveis ao divórcio e separação judicial em todos os Estados-Membros participantes. Uma aplicação substancialmente diferente da lei designada aplicável ao divórcio,

${ }^{43}$ Cf. Lei $15 / 2005$, de 8 de julho. Em certos casos excecionais, o divórcio pode ser pedido e decretado sem que este prazo tenha decorrido.

${ }^{44}$ Conclusões do Advogado-Geral Evgeni Tanchev, apresentadas em 26 de março de 2020, C-249/19, ECLI:EU:C:2020:231, considerando . $^{\circ} 65$.

${ }^{45}$ Cf. artigo $151 .^{\circ}$ do Código Civil italiano.

${ }^{46}$ Conclusões do Advogado-Geral Evgeni Tanchev, apresentadas em 26 de março de 2020, C-249/19, ECLI:EU:C:2020:231, considerando n. ${ }^{\circ} 66$. 
com a possibilidade e o intuito de se obter um resultado substancialmente diferente (decisão que decrete o divórcio sem decisão judicial prévia de separação judicial e sem o decurso de tempo mínimo de duração dessa separação), conduz, necessariamente, a um reavivar do forum shopping.

23. O Advogado-Geral invoca, em favor da solução, os princípios (de Direito da União Europeia) da equivalência e da efetividade. Em nossa opinião, estes dois princípios não impõem a solução proposta. O direito concedido pelo Direito da União Europeia que pode estar aqui em causa é o de intentar a ação de divórcio junto dos tribunais romenos, nos termos do artigo 3. ${ }^{\circ}$ do Regulamento Bruxelas II bis. Salienta-se que a norma confere apenas o direito a intentar a ação e não o direito a obter uma decisão que decrete o divórcio. Estes princípios impõem, quando muito, uma decisão sobre o mérito da causa. O que, como se viu supra em 19., é perfeitamente possível no caso concreto, e conduz a uma decisão de improcedência.

A isto acresce que, no caso concreto, não se coloca qualquer questão de (eventual) denegação de justiça. O cônjuge autor podia intentar qualquer ação matrimonial (divórcio, separação judicial e anulação do matrimónio) junto dos tribunais romenos ou italianos. Intentada a ação de divórcio sem previamente obter uma decisão de separação judicial junto dos tribunais romenos, e julgada a mesma improcedente, não ficam os cônjuges impossibilitados de obter uma decisão de divórcio ${ }^{47}$. O cônjuge autor pode sempre conseguir a dissolução do vínculo matrimonial, intentando previamente a ação de separação judicial junto dos tribunais italianos e, decorrido o prazo estabelecido na lei italiana, intentando ação de divórcio junto dos tribunais romenos ou italianos.

24. Por fim, o Advogado-Geral sustenta, em benefício da solução proposta, o lugar paralelo da norma sobre adaptação dos direitos reais, prevista nos Regulamentos sobre sucessões, sobre regimes matrimoniais e sobre efeitos patrimoniais das parcerias registadas, bem como a norma que consagra regras especiais sobre a nomeação e os poderes dos administradores de heranças em determinadas situações do Regulamento sobre sucessões, assinalando que, embora o Regulamento Roma III não contenha norma expressa a qual se possa reconduzir a solução proposta, o mesmo também não a proíbe expressamente.

Contesta-se que as normas sobre adaptação dos direitos constituam um lugar paralelo. O que essas normas estabelecem é a substituição (ou transposição) de um direito material previsto na lei X (no caso, a italiana) para o equivalente mais próximo consagrado na lei do foro (no caso, a romena). Facilmente se conclui que a solução proposta não se contém nesta delimitação. A lei romena, como prevê apenas o divórcio, desconhece a separação judicial e não consagra um qualquer outro direito material que seja um equivalente próximo da separação judicial.

O paralelismo com as regras especiais sobre a nomeação e os poderes dos administradores de heranças em determinadas situações, consagradas no Regulamento sobre sucessões, fica, em certa medida, prejudicado, porque nesse caso é a lei do foro que estabelece determinada exigência, não prevista pela lei reguladora da sucessão. Também aqui a situação é bastante distinta da solução proposta, uma vez que o preceito autoriza os tribunais a aplicar determinadas regras da lex fori, apesar da lex successionis ser uma lei estrangeira.

\footnotetext{
${ }^{47}{ }^{\mathrm{v}}$ Como pode suceder nos casos em que um ou ambos os cônjuges pretendam dissolver um casamento entre pessoas do mesmo sexo e o Regulamento Bruxelas II bis atribua competência internacional apenas a tribunais de Estado(s)-Membro(s) participante(s) cujo Direito material não considere esses casamentos válidos. O artigo 13. ${ }^{\circ}$ do Regulamento Roma III concede ao tribunal nacional uma faculdade de opt-out. Mesmo que, segundo o Direito material aplicável, existisse o direito ao divórcio e estivessem reunidas todas as condições necessárias para o mesmo ser proferido, o tribunal nacional pode, caso entenda, não proferir o divórcio com fundamento na invalidade do casamento segundo o Direito material do foro. Esta faculdade acarreta um risco: a verificação de situações transnacionais em que não é possível obter uma decisão que conceda o divórcio. Este risco constitui uma deficiente articulação dos Regulamentos Roma III e Bruxelas II bis e justifica, por si só, a alteração das normas atributivas de competência internacional em matéria matrimonial. Infelizmente, perdeu-se uma oportunidade, pois o Regulamento (UE) 2019/1111, do Conselho, de 25 de junho de 2019, relativo à competência, ao reconhecimento e à execução de decisões em matéria matrimonial e em matéria de responsabilidade parental e ao rapto internacional de crianças (reformulação), publicado no JO L 178, de 2 de julho de 2019, doravante Regulamento Bruxelas II ter, que substituirá o Regulamento Bruxelas II bis a partir de 1 de agosto de 2022, manteve incólume esta deficiente articulação entre instrumentos da União Europeia.
} 


\section{Conclusões}

25. O Acórdão $J E$ contra $K F$ é apenas o segundo em que o Tribunal de Justiça da União Europeia se pronuncia sobre as normas do Regulamento Roma III. Questionado sobre o modo como deve ser interpretado o artigo $10 .^{\circ}$ do Regulamento, na parte em que consagra - como novo limite à aplicação do Direito material estrangeiro - a inaplicabilidade da lei designada quando esta "não preveja o divórcio", o Tribunal de Justiça da União Europeia interpreta este limite no sentido de que "abrange apenas as situações em que a lei estrangeira aplicável não preveja de forma alguma o divórcio"48. Justifica esta interpretação com a interpretação estrita da letra do preceito, o contexto da disposição - assinalando que as considerações efetuadas no considerando n. ${ }^{\circ} 26$ do Regulamento sobre a expressão "não preveja o divórcio", embora efetuadas no âmbito do artigo $13 .^{\circ}$, são extensíveis ao artigo $10 .^{\circ}-\mathrm{e}$ as finalidades prosseguidas pelo Regulamento Roma III.

Assim, este limite deve ser verificado em abstrato, ou seja, o intérprete e os órgãos aplicadores do Direito devem verificar apenas se o Direito material designado aplicável nos termos dos artigos 5. ${ }^{\circ}$ e $8 .^{\circ}$ do Regulamento Roma III consagra ou não o instituto do divórcio. Entende-se que este ponto da decisão é extensível ao outro limite à aplicação do Direito material estrangeiro (discriminação em razão do género no acesso ao divórcio e à separação judicial) consagrado no artigo $10 .^{\circ}$ do Regulamento Roma III, em virtude do modo como se encontra redigido o preceito.

26. Em obiter dictum o Tribunal de Justiça da União Europeia adere aparentemente a uma proposta de solução avançada pela Comissão Europeia e sufragada pelo Advogado-Geral. Esta proposta parece ter sido motivada pela preocupação de evitar situações de denegação de justiça (que no caso concreto não existem) e norteada por um favor divortii que parece não tomar em consideração as finalidades prosseguidas pelo Regulamento Roma III e a limitação que este opera sobre o favor divorti do Regulamento Bruxelas II bis. Crê-se, por isso, que nem a pratica jurisprudencial romena, nem a proposta de solução constituirão o melhor entendimento. Parece-nos viável e mais correto que os tribunais nacionais romenos, em casos como os do Acórdão, se pronunciem sobre o mérito, proferindo uma decisão de improcedência do divórcio com fundamento no não preenchimento das condições previstas pela lei designada aplicável nos termos do Regulamento Roma III (admitindo que o resultado da aplicação desta lei não justifica, no caso concreto, o seu afastamento, por força da reserva de ordem pública internacional). A proposta de solução não nos parece necessária, uma vez que, em casos como os do Acórdão, não se verifica uma situação de impossibilidade de obter o divórcio e, ao implicar uma reconfiguração profunda das condições previstas pela lei italiana para decretar o divórcio, colide com as finalidades prosseguidas pelo Regulamento, nomeadamente reavivando situações de forum shopping que este visou limitar.

${ }^{48}$ Acórdão do TJUE de 16 de julho de 2020, JE contra KF, C-249/19, EU:C:2020:570, parte decisória. 